\title{
DYNAMICS AND LOGIC OF COVID-19 CONTAINMENT MEASURES
}

\author{
Raskina YuV ${ }^{1}$, Novkunskaya $A A^{1}$, Barchuk $A A^{1,2} \otimes$
}

1 European University at Saint Petersburg, Saint Petersburg, Russia

${ }^{2}$ Petrov National Medical Research Center of Oncology, Saint Petersburg, Russia

The ongoing COVID-19 pandemic has confronted public health systems and world economies with serious challenges. Faced with the same disease, countries responded to the threat differently depending on their social, demographic and geographic characteristics. Based on the analysis of scientific literature, international guidances and other sources of information about infection prevention and control, this article systematizes knowledge about containment strategies developed before the current pandemic, describes challenges posed by the coronavirus outbreak and highlights solutions. Specifically, the article describes the timing and order of the introduced measures, considerations for lifting the restrictions and the impact of different containment strategies on the spread of the infection, society and economy.

Keywords: COVID-19; pandemic; non-pharmaceutical public health measures; review

Author contribution: Barchuk AA, Raskina YuV conceived the article; Raskina YuV, Novkunskaya AA wrote the manuscript; Raskina YuV prepared figures and tables. All authors contributed equally to the final version of the manuscript.

Correspondence should be addressed: Anton A. Barchuk

Gagarinskaya, 6/1, Saint Petersburg, 191187; abarchuk@eu.spb.ru

Received: 07.12.2020 Accepted: 13.12.2020 Published online: 19.12.2020

DOI: $10.47183 /$ mes.2020.025

\section{ДИНАМИКА И ЛОГИКА ПРОТИВОЭПИДЕМИЧЕСКИХ МЕР}

Ю. В. Раскина ${ }^{1}$, А. А. Новкунская ${ }^{1}$, А. А. Барчук ${ }^{1,2} 凶$

${ }^{1}$ Европейский университет в Санкт-Петербурге, Санкт-Петербург, Россия

${ }^{2}$ Национальный медицинский исследовательский центр онкологии имени Н. Н. Петрова, Санкт-Петербург, Россия

Текущая эпидемия коронавирусной инфекции COVID-19 породила целый ряд вызовов для организации здравоохранения и экономики стран мира. Несмотря на то что все государства столкнулись с одним и тем же заболеванием, принимаемые экономические и организационные меры сдерживания его распространения заметно различаются в зависимости от их социальных, демографических и географических характеристик. Основываясь на аналитическом обзоре исследовательской и научной литературы, международных руководств и других источников, посвященных противоэпидемиологическим мерам, данная работа систематизирует знания о стратегиях сдерживания эпидемий, разработанных до текущей пандемии, и описывает вызовы, которые поставила перед миром вспышка нового коронавируса, и решения, принятые для ее предотвращения. В частности, показано, в какой последовательности и комбинации страны вводили разные меры, чем они руководствовались при отмене ограничений, а также то, как исследователи анализировали влияние разных стратегий борьбы с эпидемией не только на распространение инфекции, но и на социальные и экономические процессы.

Ключевые слова: COVID-19; пандемия, нефармацевтические меры общественного здравоохранения; обзор

Вклад авторов: А. А. Барчук, Ю. В. Раскина - идея статьи; Ю. В. Раскина, А. А. Новкунская — подготовка рукописи; Ю. В. Раскина — подготовка рисунков и таблиц. Все авторы принимали равное участие в правке, обсуждении и утверждении окончательной версии статьи.

$\bowtie$ Для корреспонденции: Антон Алексеевич Барчук

ул. Гагаринская, д. 6/1, г. Санкт-Петербург, 191187; abarchuk@eu.spb.ru

Статья получена: 07.12.2020 Статья принята к печати: 13.12.2020 Опубликована онлайн: 19.12.2020

DOI: $10.47183 /$ mes.2020.025

The first cases of the respiratory infection caused by the novel coronavirus SARS-CoV-2 were reported in Wuhan (South China) in December 2019. The infectious disease later termed COVID-19 (the acronym of coronavirus disease 2019) rapidly spread the globe. On March 11, WHO declared a pandemic [1]. The worst pandemics of the 20th century were caused by influenza viruses. With every new pandemic, researchers and public health experts learn more about the dynamics of such infections and refine measures for slowing their transmission and so reducing the number of new cases and deaths. Interventions that break the chain of virus transmission between humans are key in halting the spread of infection. They include identification and subsequent isolation of infectious individuals, contact tracing and quarantine of suspected cases and practices for reducing the risk of contracting the virus, such as good personal hygiene and social distancing in the first place. During the current pandemic, governments took unprecedented nationwide measures to prevent healthcare capacities from overwhelming and curb the risks of infection. Unfortunately, those containment measures came at a cost: they caused tremendous damage to economies, public welfare, health and psychological wellbeing. At the outset, the decisions made were based on the experience of past pandemics. However, over time more and more new, long-term restrictions were imposed; some of them were perceived as extreme, with unjustifiably high costs for the society. Today, as many countries are preparing to reintroduce strict anti-COVID measures, it is time the experience of world governments was summarized and relaxation strategies were discussed.

\section{Containment measures and their types}

Strategies for countering epidemics aim at slowing the transmission of the virus, suppressing and preventing its outbreaks. Actions that can be taken by individuals, communities, organizations, and governments to prevent or slow the spread of infection can be broken down into a few categories [2-4]:

- surveillance and rapid response to identify and isolate infectious individuals, trace and quarantine their contacts;

- personal protective measures (good hand hygiene, 
physical distancing, respiratory etiquette, wearing face masks that cover the mouth and nose);

- environmental measures (surface and object cleaning, using UV light, improving ventilation and adjusting air humidity);

- physical and social distancing in public spaces (physical distancing, limitations on mass gatherings or their cancellation, avoiding crowds on public transport, in restaurants, theaters or shops, school closures and distance learning, working from home, restrictions on visiting public spaces);

- travel restrictions to prevent the spread of the virus to other regions (travel advice, planning trips in advance to avoid congestion at railway stations, bus terminals and airports, restricting or banning region- or nationwide trips);

- special measures can be imposed to protect certain groups of population: those at risk for developing severe infection, individuals in institutional care (care homes, prisons, etc.), or those occupationally exposed to the virus.

There are other measures that are not directly associated with halting the transmission of the virus but that can make a significant contribution to fighting the epidemic [5]. For example, governments can:

- establish /summon emergency management agencies and declare a state emergency;

- invest funds in the research and development of vaccines and treatments;

- strengthen public health systems, i.e. institute measures for improving public health funding, satisfying the need for hospital supplies and equipment, reshaping work environments for healthcare workers and other specialists;

- expand the arsenal of social relief tools that minimize the negative impact of the imposed restrictions on the socioeconomic activity of the population, including measures to support economy, financial aid to individuals and federal agencies.

Thus, governments have a broad armamentarium of strategies to reduce contact rates between people and curb the transmission of the virus. If successful, these interventions curtail the epidemic and spread the number of infected cases over time, preventing public health capacities from overburdening. However, prior to deciding on the type, timing and intensity of containment measures, their effectiveness should be thoroughly analyzed, which may be a challenge due to a possible lack of information about the novel pathogen, as was the case with SARS-CoV-2.

The effectiveness of containment measures is determined by many variables, from demographic to geographic. Poor compliance remains a problem. The decision to self-isolate and keep social distance is largely determined by income and employment type. Residents of high-income countries with sustainable social welfare policies, as well as affluent citizens, are at lower risk of losing their source of income during an epidemic and have better chances to cope should this risk occur.

Lastly, when imposing containment measures, governments should not ignore their "side effects", i.e. social implications and economic costs.

\section{What did we know about the efficacy of containment measures before COVID-19?}

Previous pandemics of respiratory infections were caused by influenza viruses. The pandemic triggered by Spanish flu (virus A (H1N1)) in 1918-1919 was the largest: it is estimated to have killed 20-50 million people. Smaller pandemics occurred in 1957-1958 (Asian flu, virus A (H2N2)), in 1968 (Hong-Kong flu, virus A (H3N2), with 1-4 million fatalities each, and in 20092010 (virus A (H1N1), with the death toll of 100,000-400,000 $[6,7]$. The $21^{\text {st }}$ century has already witnessed 2 coronavirus epidemics of SARS in 2002 and MERS in 2012, but neither of them spread globally. SARS infected about 8,000 and killed 800 people, whereas MERS, 2,500 and 850 people, respectively [8].

Measures for containing the spread of COVID-19 were largely based on the information obtained during those epidemics.

In 2019, WHO released a systematic review of nonpharmaceutical public health measures for mitigating the risk and impact of endemic and pandemic influenza [2]. This metaanalysis focused on the effectiveness of non-pharmaceutical interventions using data from MEDLINE, PubMed, EMBASE, Cochrane library and Cochrane Central Register of Controlled Trials. Final recommendations accounted for the level of evidence, weighted benefits against costs of implementation, assessed feasibility of the interventions and the resources needed (Table. 1).

Unfortunately, for some interventions the quality and amount of evidence are insufficient to conclude that the intervention should or should not be implemented during an influenza pandemic. For example, in contrast to UV light that has been proved ineffective, the effectiveness of border closure is debatable due to the dearth of data. Studies addressing the effects of containment measures during SARS and MERS epidemics are even scarcer. In 2015, WHO released a Guidance for infection prevention and control during health care for probable or confirmed cases of Middle East respiratory syndrome coronavirus (MERS-CoV), which was updated in 2019 [10]. According to the Guidance, "humanto-human transmission occurs mostly in health-care settings and, to a more limited extent, within communities, mainly in households... Further research is needed to understand the risk factors for viral transmission from animals to humans and between humans". The Guidance thus focused on healthcare provision for infected individuals in inpatient facilities; no recommendations were proposed for outpatients, communities and governments.

Of note, the Guidance does not list contact tracing and quarantine for exposed individuals because these measures are ineffective in case of influenza. The fact that COVID-19 can be asymptomatic and that asymptomatic cases contribute significantly to its spread was established later. An infected person appears to be able to transmit the virus 2-3 day before the onset of symptoms, suggesting that contact tracing and quarantine of exposed individuals is a very effective containment measure $[11,12]$.

As a personal protective measure, wearing gloves was strongly recommended and even was mandatory in some Russian regions. But gloves are not mentioned in $\mathrm{WHO}$ guidelines as a measure to contain the spread of influenza [2] or COVID-19 [4]. Moreover, there is evidence that health damage provoked by wearing gloves outweighs the benefits [13].

\section{Open-access data for analysis of COVID-19 containment measures}

Governments across the world took unprecedented action to contain the spread of COVID-19. From the outset of the pandemic, researchers have been monitoring the measures taken and collecting valuable data that can now be used to develop effective strategies against the virus. Below, we provide a few examples of such collections. 
Table 1. Recommendations on introducing non-pharmaceutical interventions according to the severity of epidemic or pandemic flu (adapted from [2])

\begin{tabular}{|c|c|c|}
\hline Severity* & Pandemic & Epidemic \\
\hline Any & $\begin{array}{c}\text { Hand hygiene } \\
\text { Respiratory etiquette } \\
\text { Face masks for symptomatic individuals } \\
\text { Surface and object disinfection } \\
\text { Increased ventilation } \\
\text { Isolation of sick individuals } \\
\text { Travel advice }\end{array}$ & $\begin{array}{c}\text { Hand hygiene } \\
\text { Respiratory etiquette } \\
\text { Face masks for symptomatic individuals } \\
\text { Surface and object disinfection } \\
\text { Increased ventilation } \\
\text { Isolation of sick individuals } \\
\text { Travel advice }\end{array}$ \\
\hline Moderate & $\begin{array}{c}\text { As above plus } \\
\text { Avoiding crowding }\end{array}$ & $\begin{array}{l}\text { As above plus } \\
\text { Avoiding crowding }\end{array}$ \\
\hline High & $\begin{array}{c}\text { As above plus } \\
\text { Face masks for everyone } \\
\text { School measures and school closures }\end{array}$ & $\begin{array}{c}\text { As above plus } \\
\text { Face masks for everyone } \\
\text { School measures and school closures }\end{array}$ \\
\hline Extraordinary & $\begin{array}{c}\text { As above plus } \\
\text { Workplace measures, workplace closures } \\
\text { Internal travel restrictions }\end{array}$ & $\begin{array}{c}\text { As above plus } \\
\text { Workplace measures, workplace closures }\end{array}$ \\
\hline Not recommended & $\begin{array}{c}\text { UV light } \\
\text { Modifying air humidity } \\
\text { Contact tracing } \\
\text { Quarantine of exposed individuals } \\
\text { Entry and exit screening } \\
\text { Border closure }\end{array}$ & $\begin{array}{c}\text { UV light } \\
\text { Modifying air humidity } \\
\text { Contact tracing } \\
\text { Quarantine of exposed individuals } \\
\text { Entry and exit screening } \\
\text { Internal travel restrictions } \\
\text { Border closure }\end{array}$ \\
\hline
\end{tabular}

Note: * - Pandemic influenza severity assessment (PISA) was based on the transmissibility of the virus, severity of the disease and its impact on public health and society. Five levels are distinguished: no activity/activity below seasonal threshold, low, moderate, high, and extraordinary activity [9] (based on [2]).

WHO Public health and social measures (WHO PHSM)

The database [14] comprises data aggregated from different credible sources and classified into the following categories:

- biological measures;

- drug-based measures;

- environmental measures;

- individual measures:

- international travel measures;

- other measures;

- social and physical distancing measures.

The first two classes are closely linked to the trialing of drugs, vaccines, etc. (these categories are rarely included in other datasets describing measures against COVID-19). The "Other measures" class refers to all economic measures initiated by governments, e.g. working from home.

Example: on March 22, the government of Germany banned gatherings of more than 2 people: 2 people could meet up if they kept physical distance of at least $1.5 \mathrm{~m}$. According to the classification scheme listed above, this measure falls under the "Social and physical distancing measures" class, the "Gatherings, businesses and services" subclass and the "Cancelling, closing, restricting or adapting public gatherings outside the home" action.

At the time of writing, there was no information about the timing of the implemented measure although the column was present in the classification table.

\section{COVID19 Government Measures Dataset}

This database was created under the non-profit nongovernmental international ACAPS project [15]. Categories:

- social distancing;

- movement restrictions;

- public health measures;

- social and economic measures;

- lockdowns.

Example: the German ban on gatherings of more than 2 people falls under the "Social distancing" category, the "Limit public gatherings" measure and is described as "Limit to the number of people that can meet in public and private spaces."

\section{The Oxford COVID-19 Government Response Tracker (OxCGRT)}

It is probably the most consulted source that provides information about government response to epidemics and proposes a few indicators for quantitative analysis, which considerably simplifies inter-country comparisons [16].

OxCGRT accumulates information on containment measures implemented by world governments and gauges government response using 17 indicators. Of them, 8 refer to virus containment (school closure, travel restriction). Five indicators reflect public health policies (testing, emergency investment in public health). Four indicators characterize economic policies (income support).

Based on these indicators, 4 indices have been developed, each of them being a number between 0 to 100 [17]: 1) the overall government response index sums up all government actions for each indicator type, showing how the government response transformed over time, becoming stronger or weaker during the outbreak; 2) the stringency index reflects the stringency of the restrictions (imposed on the population in the first place), including lockdowns, restrictions on travel, mass gatherings, and social distancing; 3) the containment and health index evaluates a combination of stringent policies and public health measures (testing, contact tracing, investment into vaccine development, etc.); 4) the economic support index.

With indices that simplify quantitative analysis, accuracy will be inevitably sacrificed for convenience. For example, restrictions on mass gatherings are classified using the following scale:

0 - no restrictions;

1 - restrictions on very large gatherings (over 1,000 people);

2 - restrictions on gatherings between 101 and 1,000 people;

3 - restrictions on gatherings between 11 and 100 people;

4 - restrictions on gatherings of 10 people or less.

Thus, restrictions on mass gatherings for 2, 5 and 10 people score the same on the proposed scale. 
The scale for school and university closures seems to be even rougher:

0 - no measures;

1 - recommend closing;

2 - require closing (only some levels or categories);

3 - require closing all levels.

In some countries, long-term closures were forced on all educational institutions. In others, universities and schools were not

A

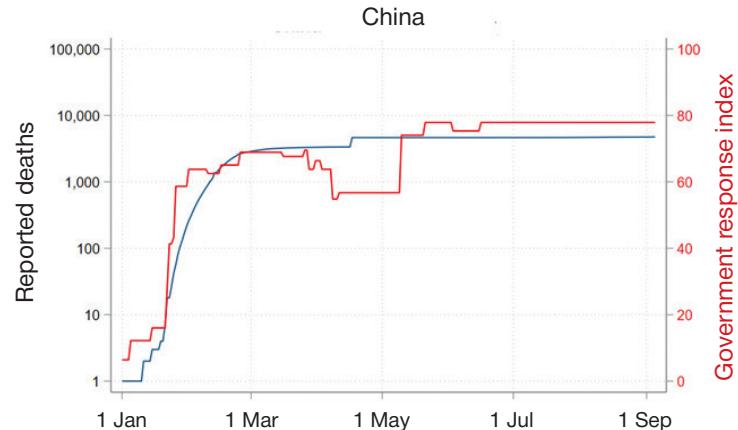

C

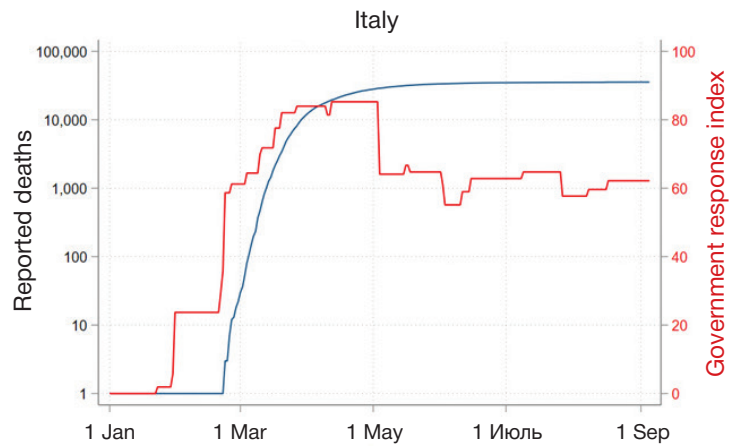

E

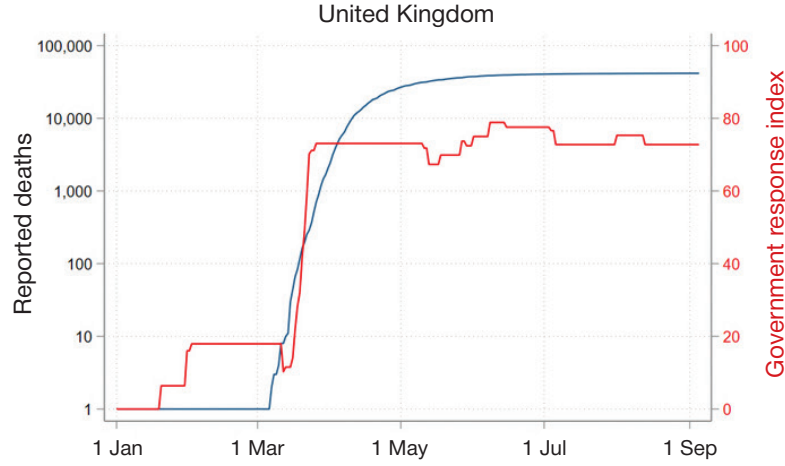

G

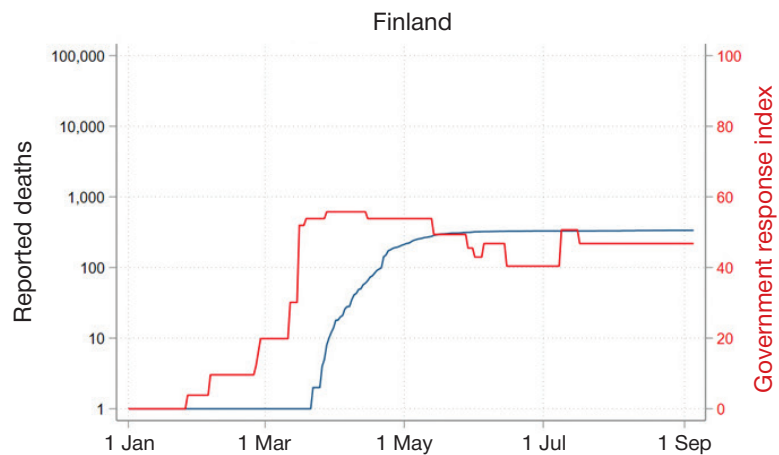

closed simultaneously, or shutdowns were mandated for some levels only (primary schools), or schools remained open only for the children of residents involved in essential continuous production cycle enterprises. Some nuances were lost while evaluating the stringency of the implemented measures. Summing up, indices are simple and effective tools for comparing containment measures taken by the governments of different countries. To analyze an individual country, desegregated indices of its policies should be used.

B

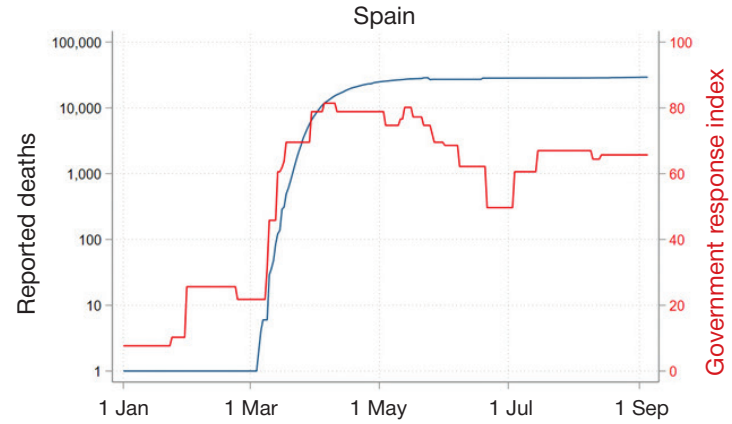

D

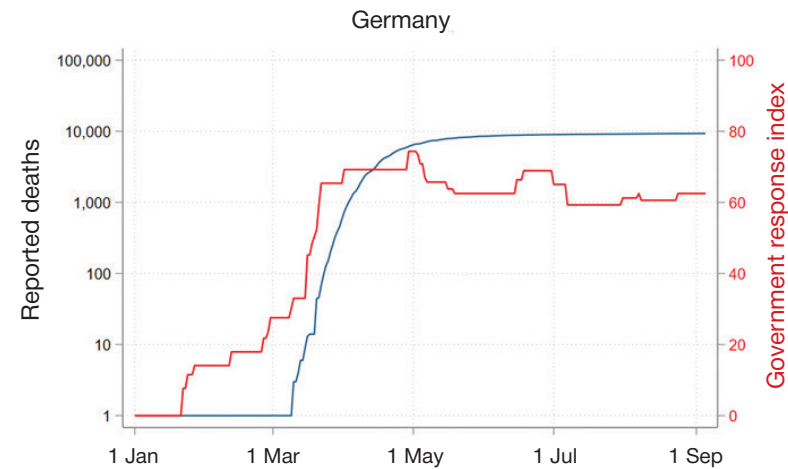

F

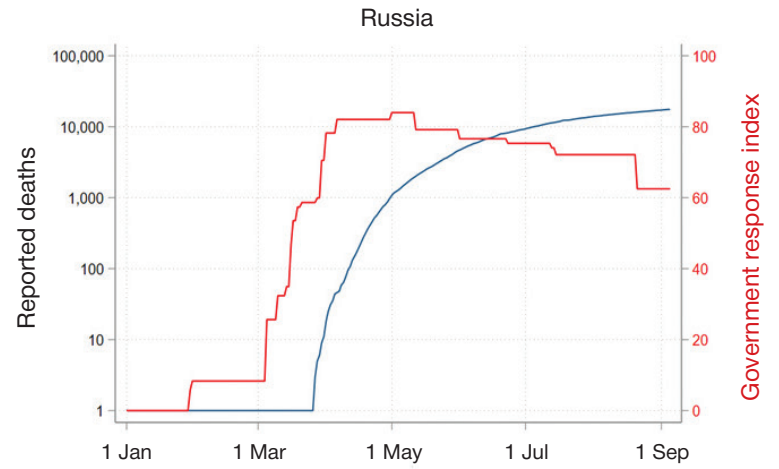

$\mathrm{H}$

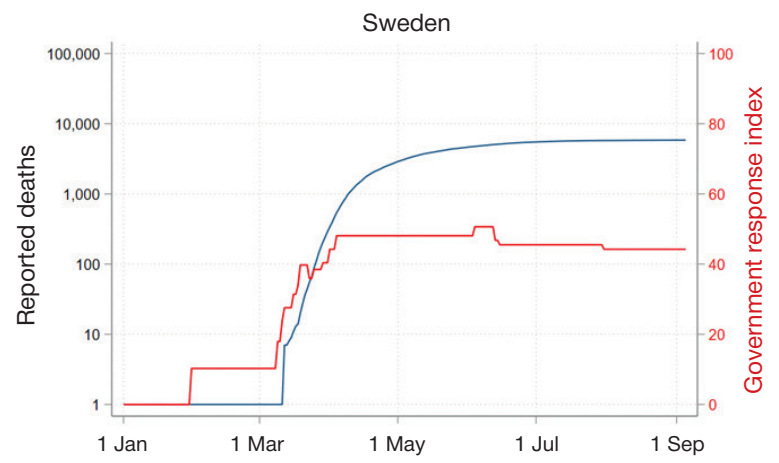

Fig. 1. The dynamics of the overall government response index proposed by OxCGRT and the number of confirmed deaths in 8 countries. The reported number of deaths is plotted on the left axis; the government response index is plotted on the right axis; its curve almost repeats the shape of the curve for the number of confirmed cases [16] 


\section{When and how did countries introduce containment measures?}

At the outset of the pandemic, governments had to rely on the recommendations based on the experience of past epidemics and pandemics and navigate in uncertainty as there was no information about the novel virus and the disease it caused. The severity of an epidemic depends on the transmissibility of the virus (see Table 1), which back then was unknown. It was impossible to determine the number of infectious individuals and difficult to count all the sick. The main routes of transmission were only hypothetical, no information was available about the early symptoms and the course of the disease; its incubation period was uncertain. It was not clear how big a gathering had to be to be banned: over 1,000 people? Over 500? Over 50? Should people not congregate in groups over 3 ? Since the start of the pandemic, even the general public has become accustomed to the term "effective reproductive number", understood the difference between lethality and mortality rates, and started to realize that governments took decisions based on the available information.

Fig. 1A-H illustrate the dynamics of the overall government response index (OxCGRT) and the number of deaths from COVID-19 in 8 countries. Shortly after the initial outbreak in China, it became clear that the virus was spreading at a sweeping pace and its impact on public health systems would be immense. Severe patients required a complex lengthy and resource-consuming treatment. It was estimated that healthcare capacity, which takes time to increase, would be overwhelmed if the rate of spread and the death toll would continue to grow at the same pace. So, governments hurried to take large-scale action. In late April and early May, Spain and Italy urgently introduced harsh measures to control the spread of the virus. The measures (the red line in the figure) were triggered in the wake of the exponential growth of confirmed COVID-19 cases (not shown in the figure) and the soaring number of deaths (the blue line). In the UK, Boris Johnson's government faced a barrage of criticism for delaying the introduction of stringent containment measures. In Germany, the government response followed the trajectory of confirmed cases and was slightly ahead of the death curve. In Russia, strict measures were somewhat preemptive, drawing on the experience of Western countries. In Finland, interventions were more stringent and urgent than in Sweden, but on the whole the stringency index for Nordic countries was more than 20 points lower than in Spain, Italy, and Russia.

Protracted stringent measures, specifically quarantine, may have a disincentive effect: over time, people (and society in general) grow reluctant to comply with the restrictions [18]. A review by a team of medical psychologists provides evidence of negative psychological effects exerted by quarantine [19]. Self-isolation and lockdowns lead to post-traumatic stress, depression, and anger that last long after the restrictions are lifted (up to 3 years); there is also evidence that voluntary selfisolation is better tolerated than mandatory [19].

Perhaps, Sweden took heed of those warnings. When the pandemic started, Sweden was harshly criticized for its weak policies. However, maybe it won strategically, averted an economic recession and did not disincentivize the population to comply with the restrictions. As a result, the Swedish population is likely to be far more cooperative with their government during the second and subsequent epidemic waves than populations of other European countries. It is speculated that the UK government was trying to delay stringent measures in an effort to find the right time when lockdown benefits outweighed its costs, so that the fatigue felt by the population would not disrupt the positive effects of quarantine.

\section{When and why were strict measures relaxed?}

Containment measures were relaxed (or maintained, as in China, UK and Finland) when the number of deaths reached the plateau (see Fig. 1). Russia is an exception here because it eased the measures at the time when death rates were growing. Relaxation and reintroduction of containment measures is a stepwise process that largely depends on the number of confirmed cases and fatalities, as well as new information about transmission routes. The epidemiological situation in the region determines the order in which containment measures will be lifted. Agencies responsible for infection prevention and control and regional governors estimate the number of sick individuals and compare it against healthcare capacities in order to prevent the public health system from overwhelming. WHO suggests that at least 6 criteria should be accounted for when deciding on the timing for lifting containment measures [20].

1. COVID-19 spread is confirmed to be under control.

2. Public health system capacities are sufficient for timely identification, isolation, testing, contact tracing and quarantine.

3. Vulnerable populations are protected: risks of outbreaks in care homes and psychiatric facilities have been minimized the same pertains to mass gatherings.

4. Measures for COVID-19 prevention in the workplace are strictly adhered to, including social distancing, good hand hygiene and respiratory etiquette.

5. Risks of "importing" the infection from other regions can be adequately managed.

6. The public is aware of the situation and ready to cooperate.

Another factor that affects the order in which measures may be relaxed is local culture, including compliance of the population with the recommendations and restrictions, significance of social contacts or activities in the particular cultural setting. Many countries develop response frameworks that allow for some variation across different regions depending on the local culture, which determines the priority of public places that should open first and their working hours, the need to self-isolate for people from other regions, the stringency of restrictions on mass gatherings, etc. Many countries are also developing long-term lifestyle and work model, i.e. rules that will be perceived as a new normal until the virus is no longer a threat.

So far, general recommendations regarding physical distancing, hand hygiene, respiratory etiquette and wearing face masks in certain settings remain in force in most countries affected by COVID 19. However, restrictions can be mitigated or toughened at any time, and anti-COVID policies are updated almost every week. For instance, it was only in midAugust that ban on marriage ceremonies (with no more than 30 guests present) was lifted in the UK and spas and some other small businesses opened; in some UK regions in-home mass gatherings of over 10 persons are still prohibited . Russia relaxed some of the strict measures in June and July although the virus had spread to our country later than to most European countries; this may be explained to regional differences. The measures that are still in force in Russia include wearing face masks in public places and thorough disinfection. At the same time, Finland, which was the first to open schools and did not have a face mask mandate in the spring of 2020, issued a recommendation for the public in mid-August on wearing face masks on public transport; this decision may be regarded as an introduction of new measures for preventing the spread of the coronavirus infection. 


\section{Assessing effectiveness of containment measures and their impact on economy}

Decisions on instituting containment measures and assessment of their effectiveness at different stages of the pandemic require robust, reliable, up-to-date data on the infection itself and the mobility, behavior and compliance of the population. Understanding the dynamics of population mobility and population response to the introduced interventions will help to 1) predict the geographic spread of the disease and thus estimate future risks, demands and implementation potential, and 2) identify causal links and mechanisms and assess the contribution of each measure, which may improve the effect of their implementation [21]. Such data can be acquired through different routes.

Surveys are a traditional tool for collecting data. They are useful in tracing social contacts, estimating the impact of the introduced interventions on income and employment, and measuring public support. A survey was launched in the UK a day after the lockdown started [22]. The survey was conducted in a representative sample of adults. Respondents were asked about contacts they had had on the previous day and report the events they had planned to visit during the preceding week but had to cancel. Respondents were asked about their adherence to social distancing requirements during thew preceding week. Respondents provided information on members of their households who had been recommended to self-isolate or limit their time at work or at an educational institution. They were also asked whether they had reduced the number of social contacts voluntarily and if so, how. Thus, the researchers created models and compared the number of social contacts before and during the lockdown. Then they analyzed changes in $\mathrm{RO}$ following the introduction of physical distancing measures. It was found that the average daily number of contacts per participants decreased by $74 \%$ (from 10.8 to 2.8) during the lockdown. This was enough for $\mathrm{RO}$ to fall from the pre-lockdown value of 2.6 to 0.62 (95\% Cl: $0.37-0.89)$ for all types of contacts during the lockdown and to 0.37 (95\% Cl: 0.22-0.53) for skin-to-skin contacts.

Digital data, including data from mobile phones, are an important analytical tool as they help to monitor the dynamics of population mobility in almost real time and therefore are very useful in predicting the spread of infection and the effectiveness of measures taken [23]. A good example is data from [24]. The study sought to understand the effect of measures implemented by state and local governments (emergency declarations, school closures, rules for restaurants, restrictions on mass gatherings, business closures, stay-at-home mandates) on social distancing at the outset of the epidemic in the USA. The researchers analyzed geolocation data from mobile apps collected by private companies. The data included information about the number of mobile phones simultaneously present at a location visited by the owner of the tracked mobile device during the day; about the time spent by the owner at home and outdoors; about the relocation of the device across the state and to other states. Considering that measures taken by different states were not introduced simultaneously and varied in intensity, the authors of the study concluded that adequate information and recommendations were as effective in reducing mobility as enforced social distancing measures.

Instantaneous contact tracing by means of a mobile application and subsequent automated notification of close contacts may be sufficient to halt the epidemic if the app is used by a high proportion of the population [26]. Supported by the European Commission, the eHealth Network initiative developed a set of tools for creating and using contact tracing apps compliant with the EU principles of confidentiality and data protection [27].

Epidemiological models are another tool widely exploited to assess the effectiveness of containment measures. Using examples from the literature, the authors of the study [28] developed a SEIR model to simulate measures for infection prevention and control varying in duration and intensity for one year. The study demonstrates that physical distancing measures should be lifted gradually in order to avoid peak incidence and prevent public health systems from collapsing.

More complex epidemiological-economic models account for individual behaviors in response to the threat of infection [29]. Studies demonstrate the effectiveness of aggressive containment policies and early, stringent social distancing measures aimed to reduce death rates and mitigate economic costs [30-33]. New models for analyzing the effectiveness of public health measures are underway. For example, a Bayesian model was developed that estimates transmission from observed deaths and simulates a hypothetical counterfactual scenario to estimate the number of deaths that would have occurred if containment measures had not been introduced [34]. According to the study, the introduced public health interventions led to a drop in Rt below 1 and thus helped to avoid 3,100,000 deaths in 11 European countries.

Some studies emphasize that testing for COVID-19 and the subsequent isolation of infected individuals reduces the need for stringent social distancing measures and thus allows finding a tradeoff between low economic activity and public health [35-37].

A multi-risk SIR model (MR-SIR) in which the rates of infection, hospitalization and fatality varied between different age groups (young, middle-aged and old) showed that optimal measures differentially targeting risk/age groups worked significantly better than "one-size-fits-all" measures targeting the entire population; the analysis revealed that at the same level of economic damage greater gains (in terms of fatality reduction) could be achieved if stricter isolation policies were applied to the oldest group [38]

Importantly, working from home may not be an option for every sector of the economy; this should be accounted for when lifting the restrictions. A broad "reopening" of the economy is still possible if stringent restrictions are imposed on social contacts outside work (mass social gatherings, attending restaurants, bars, etc.) [39, 40].

\section{CONCLUSION}

Despite the rapidly growing number of studies addressing the effectiveness of public health and social measures and their implications for the economy and society, the accumulated data are still insufficient to draw firm conclusions about their relevance and adequate timing. The scope and stringency of measures introduced to contain the spread of COVID-19 were unprecedented. Some of them (contact tracing, restrictions on international travel, physical distancing) were tested and applied for the first time in history.

The order, timing and the scope of public health and social measures depends on the social, demographic and geographic characteristics of a country. Besides, success in curtailing the epidemic is to some extent determined by the experience the country had with other infections, its healthcare capacities and economic development. Importantly, the effectiveness and consequences of containment measures can vary across different social groups within the same country: during 
the ongoing COVID-19 pandemic, elderly and low-income populations turned out to be the most vulnerable.

Differences in the stringency and timing of containment measures between countries can be analyzed using databases that gauge government responses using a set of indicators and indices. Such indices simplify data comparison but have certain limitations because they provide very rough estimates for individual cases or regions. Disaggregated data should be used to assess the effectiveness of containment measure within a given country. Besides, as the pandemic is continuing, the data are being accumulated and databases are being upgraded, so the effects of containment measures on the economy, social and political institutions are yet to be elucidated.

Although containment strategies turned out to be quite effective and significantly slowed or halted the spread of the novel coronavirus in some countries, the society and the world economy are still facing challenges posed by the pandemic and therefore have to develop new interventions to counter the threat.

\section{References}

1. WHO. WHO Director-General's opening remarks at the media briefing on COVID-19-11, March 2020. World Health Organization. Available from: https://www.who.int/dg/speeches/ detail/who-director-general-s-opening-remarks-at-the-mediabriefing-on-covid-19---11-march-2020.

2. WHO. Non-pharmaceutical public health measures for mitigating the risk and impact of epidemic and pandemic influenza: annex: report of systematic literature reviews. World Health Organization. Available from: https://apps.who.int/iris/handle/10665/329439.

3. WHO. Calibrating long-term non-pharmaceutical interventions for COVID-19: principles and facilitation tools. Manila: WHO Regional Office for the Western Pacific. Available from: https://apps.who. int/iris/handle/10665/332099.

4. WHO. Overview of public health and social measures in the context of COVID-19: interim quidance, 18 May 2020. World Health Organization. Available from: https://apps.who.int/iris/ handle/10665/331773.

5. WHO. Tracking Public Health and Social Measures. A global database of public health and social measures applied during the COVID-19 pandemic. Available from: https://www.who.int/ emergencies/diseases/novel-coronavirus-2019/phsm (2020, accessed 26 July 2020).

6. Kilbourne ED. Influenza pandemics of the $20^{\text {th }}$ century. Emerging infectious diseases 2006; 12: 9 .

7. Peiris $\mathrm{JM}, \mathrm{Tu} W$, Yen $\mathrm{H}$. A novel H1N1 virus causes the first pandemic of the 21st century. European journal of immunology. 2009: 39: 2946-54.

8. Mahase E. Coronavirus: covid-19 has killed more people than SARS and MERS combined, despite lower case fatality rate. BMJ; 368. Epub ahead of print 18 February 2020. DOI: 10.1136/ bmj.m641.

9. WHO. Pandemic influenza severity assessment (PISA): a WHO guide to assess the severity of influenza in seasonal epidemics and pandemics. World Health Organization, 2017.

10. WHO. Infection prevention and control during health care for probable or confirmed cases of Middle East respiratory syndrome coronavirus (MERS-CoV) infection: interim guidance: updated October 2019. World Health Organization, 2019.

11. He X, Lau EH, Wu P, et al. Temporal dynamics in viral shedding and transmissibility of COVID-19. Nature medicine. 2020; 26: 672-5.

12. Koo JR, Cook AR, Park M, et al. Interventions to mitigate early spread of SARS-CoV-2 in Singapore: a modelling study. The Lancet Infectious Diseases. 2020; 20: 678-88.

13. European Centre for Disease Prevention and Control. Use of gloves in healthcare and non-healthcare settings in the context of the COVID-19 pandemic. Stockholm: ECDC, 2020.

14. WHO Public health and social measures (WHO PHSM). Available from: https://www.who.int/emergencies/diseases/novelcoronavirus-2019/phsm

15. COVID-19 Government Measures Dataset. Available from: https:// www.acaps.org/covid-19-government-measures-dataset.

16. The Oxford COVID-19 Government Response Tracker (OxCGRT). Available from: https://www.bsg.ox.ac.uk/research/researchprojects/coronavirus-government-response-tracker.

17. Hale $\mathrm{T}$, Petherick A, Phillips $\mathrm{T}$, et al. Variation in government responses to COVID-19. Blavatnik school of government working paper; 31.

18. Lunn PD, Belton CA, Lavin C, et al. Using Behavioral Science to help fight the Coronavirus. Journal of Behavioral Public Administration; 3 .

19. Brooks SK, Webster RK, Smith LE, et al. The psychological impact of quarantine and how to reduce it: rapid review of the evidence. The Lancet. 2020; 395: 10227: P912-920. DOI: 10.1016/S01406736(20)30460-8

20. WHO Europe. Considerations in adjusting public health and social measures in the context of COVID-19: interim guidance, 12 May 2020. World Health Organization, 2020.

21. Oliver N, Lepri B, Sterly H, et al. Mobile phone data for informing public health actions across the COVID-19 pandemic life cycle. Science Advances. 2020; 6: eabc0764.

22. Jarvis $\mathrm{Cl}$, Van Zandvoort K, Gimma A, et al. Quantifying the impact of physical distance measures on the transmission of COVID-19 in the UK. BMC medicine. 2020; 18: 1-10.

23. Ienca $\mathrm{M}$, Vayena $\mathrm{E}$. On the responsible use of digital data to tackle the COVID-19 pandemic. Nature medicine. 2020; 26: 463-4

24. Gupta S, Nguyen TD, Rojas FL, et al. Tracking Public and Private Responses to the COVID-19 Epidemic: Evidence from State and Local Government Actions. Working Paper 27027, National Bureau of Economic Research. Epub ahead of print April 2020. DOI: 10.3386/w27027

25. Ferretti L, Wymant $\mathrm{C}$, Kendall M, et al. Quantifying SARS-CoV-2 transmission suggests epidemic control with digital contact tracing. Science. 2020; 368: eabb6936. DOI: 10.1126/science. abb6936.

26. Raskar R, Schunemann I, Barbar R, et al. Apps gone rogue: Maintaining personal privacy in an epidemic. arXiv preprint arXiv:200308567.

27. eHealth Network. Mobile applications to support contact tracing in the EU's fight against COVID-19: Common EU Toolbox for Member States. Available from: https://ec.europa.eu/health/sites/ health/files/ehealth/docs/covid-19_apps_en.pdf.

28. Prem K, Liu Y, Russell TW, et al. The effect of control strategies to reduce social mixing on outcomes of the COVID-19 epidemic in Wuhan, China: a modelling study. The Lancet Public Health. 2020; 5: e261-e270.

29. Fenichel EP, Castillo-Chavez C, Ceddia MG, et al. Adaptive human behavior in epidemiological models. Proceedings of the National Academy of Sciences. 2011; 108: 6306-11.

30. Alvarez FE, Argente D, Lippi F. A simple planning problem for covid-19 lockdown. National Bureau of Economic Research, 2020.

31. Demirguc-Kunt A, Lokshin M, Torre I. The sooner, the better: The early economic impact of non-pharmaceutical interventions during the COVID-19 pandemic. World Bank Policy Research Working Paper.

32. Farboodi M, Jarosch G, Shimer R. Internal and external effects of social distancing in a pandemic. National Bureau of Economic Research, 2020

33. Jones CJ, Philippon T, Venkateswaran V. Optimal Mitigation Policies in a Pandemic: Social Distancing and Working from Home. Working Paper 26984, National Bureau of Economic Research. Epub ahead of print April 2020. DOI: 10.3386/w26984.

34. Flaxman S, Mishra S, Gandy A, et al. Estimating the effects of 
non-pharmaceutical interventions on COVID-19 in Europe. Nature. 2020; 1-5.

35. Berger DW, Herkenhoff KF, Mongey S. An SEIR infectious disease model with testing and conditional quarantine. National Bureau of Economic Research, 2020.

36. Brotherhood L, Kircher P, Santos C, et al. An Economic Model of the Covid-19 Epidemic: The Importance of Testing and AgeSpecific Policies. SSRN Scholarly Paper ID 3618840, Rochester, NY: Social Science Research Network, 2020. Available from: https://papers.ssrn.com/abstract=3618840.

37. Eichenbaum MS, Rebelo S, Trabandt M. The Macroeconomics of

\section{Литература}

1. WHO. WHO Director-General's opening remarks at the media briefing on COVID-19-11, March 2020. World Health Organization. Available from: https://www.who.int/dg/speeches/ detail/who-director-general-s-opening-remarks-at-the-mediabriefing-on-covid-19---11-march-2020.

2. WHO. Non-pharmaceutical public health measures for mitigating the risk and impact of epidemic and pandemic influenza: annex: report of systematic literature reviews. World Health Organization. Available from: https://apps.who.int/iris/handle/10665/329439.

3. WHO. Calibrating long-term non-pharmaceutical interventions for COVID-19: principles and facilitation tools. Manila: WHO Regional Office for the Western Pacific. Available from: https://apps.who. int/iris/handle/10665/332099.

4. WHO. Overview of public health and social measures in the context of COVID-19: interim guidance, 18 May 2020. World Health Organization. Available from: https://apps.who.int/iris/ handle/10665/331773.

5. WHO. Tracking Public Health and Social Measures. A global database of public health and social measures applied during the COVID-19 pandemic. Available from: https://www.who.int/ emergencies/diseases/novel-coronavirus-2019/phsm (2020, accessed 26 July 2020).

6. Kilbourne ED. Influenza pandemics of the $20^{\text {th }}$ century. Emerging infectious diseases. 2006; 12: 9 .

7. Peiris JM, Tu W, Yen H. A novel H1N1 virus causes the first pandemic of the 21st century. European journal of immunology. 2009; 39: 2946-54

8. Mahase E. Coronavirus: covid-19 has killed more people than SARS and MERS combined, despite lower case fatality rate. BMJ; 368. Epub ahead of print 18 February 2020. DOI: 10.1136/ bmi.m641.

9. WHO. Pandemic influenza severity assessment (PISA): a WHO guide to assess the severity of influenza in seasonal epidemics and pandemics. World Health Organization, 2017.

10. WHO. Infection prevention and control during health care for probable or confirmed cases of Middle East respiratory syndrome coronavirus (MERS-CoV) infection: interim guidance: updated October 2019. World Health Organization, 2019.

11. He X, Lau EH, Wu P, et al. Temporal dynamics in viral shedding and transmissibility of COVID-19. Nature medicine. 2020; 26: $672-5$.

12. Koo JR, Cook AR, Park M, et al. Interventions to mitigate early spread of SARS-CoV-2 in Singapore: a modelling study. The Lancet Infectious Diseases. 2020; 20: 678-88.

13. European Centre for Disease Prevention and Control. Use of gloves in healthcare and non-healthcare settings in the context of the COVID-19 pandemic. Stockholm: ECDC, 2020.

14. WHO Public health and social measures (WHO PHSM). Available from: https://www.who.int/emergencies/diseases/novelcoronavirus-2019/phsm.

15. COVID-19 Government Measures Dataset. Available from: https:// www.acaps.org/covid-19-government-measures-dataset.

16. The Oxford COVID-19 Government Response Tracker (OxCGRT). Available from: https://www.bsg.ox.ac.uk/research/researchprojects/coronavirus-government-response-tracker.

17. Hale T, Petherick A, Phillips T, et al. Variation in government responses to COVID-19. Blavatnik school of government working
Testing and Quarantining. National Bureau of Economic Research, 2020.

38. Acemoglu D, Chernozhukov V, Werning I, et al. A multi-risk SIR model with optimally targeted lockdown. National Bureau of Economic Research, 2020

39. Baqaee D, Farhi E, Mina MJ, et al. Reopening Scenarios. Working Paper 27244, National Bureau of Economic Research. Epub ahead of print May 2020. DOI: 10.3386/w27244.

40. Glover A, Heathcote J, Krueger D, et al. Health versus wealth: On the distributional effects of controlling a pandemic. National Bureau of Economic Research, 2020.

paper; 31

18. Lunn PD, Belton CA, Lavin C, et al. Using Behavioral Science to help fight the Coronavirus. Journal of Behavioral Public Administration; 3 .

19. Brooks SK, Webster RK, Smith LE, et al. The psychological impact of quarantine and how to reduce it: rapid review of the evidence. The Lancet. 2020; 395: 10227: P912-920. DOI: 10.1016/S01406736(20)30460-8.

20. WHO Europe. Considerations in adjusting public health and social measures in the context of COVID-19: interim guidance, 12 May 2020. World Health Organization, 2020.

21. Oliver N, Lepri B, Sterly H, et al. Mobile phone data for informing public health actions across the COVID-19 pandemic life cycle. Science Advances. 2020; 6: eabc0764.

22. Jarvis $\mathrm{Cl}$, Van Zandvoort K, Gimma A, et al. Quantifying the impact of physical distance measures on the transmission of COVID-19 in the UK. BMC medicine. 2020; 18: 1-10.

23. Ienca $\mathrm{M}$, Vayena $\mathrm{E}$. On the responsible use of digital data to tackle the COVID-19 pandemic. Nature medicine. 2020; 26: 463-4.

24. Gupta S, Nguyen TD, Rojas FL, et al. Tracking Public and Private Responses to the COVID-19 Epidemic: Evidence from State and Local Government Actions. Working Paper 27027, National Bureau of Economic Research. Epub ahead of print April 2020. DOI: 10.3386/w27027.

25. Ferretti L, Wymant C, Kendall M, et al. Quantifying SARS-CoV-2 transmission suggests epidemic control with digital contact tracing. Science. 2020; 368: eabb6936. DOI: 10.1126/science. abb6936.

26. Raskar R, Schunemann I, Barbar R, et al. Apps gone rogue: Maintaining personal privacy in an epidemic. arXiv preprint arXiv:200308567.

27. eHealth Network. Mobile applications to support contact tracing in the EU's fight against COVID-19: Common EU Toolbox fo Member States. Available from: https://ec.europa.eu/health/sites/ health/files/ehealth/docs/covid-19_apps_en.pdf.

28. Prem K, Liu Y, Russell TW, et al. The effect of control strategies to reduce social mixing on outcomes of the COVID-19 epidemic in Wuhan, China: a modelling study. The Lancet Public Health. 2020; 5: e261-e270.

29. Fenichel EP, Castillo-Chavez C, Ceddia MG, et al. Adaptive human behavior in epidemiological models. Proceedings of the National Academy of Sciences. 2011; 108: 6306-11.

30. Alvarez FE, Argente D, Lippi F. A simple planning problem for covid-19 lockdown. National Bureau of Economic Research, 2020.

31. Demirguc-Kunt A, Lokshin M, Torre I. The sooner, the better: The early economic impact of non-pharmaceutical interventions during the COVID-19 pandemic. World Bank Policy Research Working Paper.

32. Farboodi M, Jarosch G, Shimer R. Internal and external effects of social distancing in a pandemic. National Bureau of Economic Research, 2020.

33. Jones CJ, Philippon T, Venkateswaran V. Optimal Mitigation Policies in a Pandemic: Social Distancing and Working from Home. Working Paper 26984, National Bureau of Economic Research. Epub ahead of print April 2020. DOI: 10.3386/w26984. 34. Flaxman S, Mishra S, Gandy A, et al. Estimating the effects of 


\section{REVIEW I EPIDEMIOLOGY}

non-pharmaceutical interventions on COVID-19 in Europe. Nature. 2020; 1-5.

35. Berger DW, Herkenhoff KF, Mongey S. An SEIR infectious disease model with testing and conditional quarantine. National Bureau of Economic Research, 2020.

36. Brotherhood L, Kircher P, Santos C, et al. An Economic Model of the Covid-19 Epidemic: The Importance of Testing and AgeSpecific Policies. SSRN Scholarly Paper ID 3618840, Rochester, NY: Social Science Research Network, 2020. Available from: https://papers.ssrn.com/abstract=3618840.

37. Eichenbaum MS, Rebelo S, Trabandt M. The Macroeconomics of
Testing and Quarantining. National Bureau of Economic Research, 2020.

38. Acemoglu D, Chernozhukov V, Werning I, et al. A multi-risk SIR model with optimally targeted lockdown. National Bureau of Economic Research, 2020.

39. Baqaee D, Farhi E, Mina MJ, et al. Reopening Scenarios. Working Paper 27244, National Bureau of Economic Research. Epub ahead of print May 2020. DOI: 10.3386/w27244.

40. Glover A, Heathcote J, Krueger D, et al. Health versus wealth: On the distributional effects of controlling a pandemic. National Bureau of Economic Research, 2020. 